\title{
Living Apart Together as a "Family Form" Among Persons of Retirement Age: The Appropriate Family Law Response
}

\section{CYNTHIA GRANT BOWMAN*}

\section{Introduction}

As the Baby Boom generation enters retirement age, patterns of living among older persons are beginning to change. ${ }^{1}$ Unlike their predecessors, the Baby Boomers lived through the sexual revolution, divorced more easily and more often, and institutionalized new patterns of coupling, such as cohabitation. As a result, the rate of marriage has declined and the percent of the population classified as "single" has gone up. ${ }^{2}$ This age cohort has now moved into the sixty-five-plus group and makes up those we think of as the retirement generation, or the "Third Age" group. ${ }^{3}$

* Dorothea S. Clarke Professor of Feminist Jurisprudence, Cornell Law School. I am indebted to the LATs who were willing to share their experiences and insights with me in interviews.

1. The leading edge of the so-called Baby Boom is comprised of those born between 1946 and 1955. Margaret Hellie Huyck, Romantic Relationships in Later Life, 25 GenERATIONS 9, 13 (2001).

2. See Casey E. Copen et al., First Marriages in the United States: Data from the 2006-2010 National Survey of Family Growth 9 (2012), https://www.cdc.gov/nchs/ products/nhsr.htm.

3. The "Third Age" is a term used for those in or close to retirement. Huyck, supra note 1, at 13 . 
As longevity has increased and the divorce rate for this age group risen, ${ }^{4}$ growing numbers of older persons are unmarried and for longer periods. Yet they appear to have a continued desire for intimate relationships, along with an interest in more flexible forms of living. One lifestyle that many sociologists and gerontologists have noted as being particularly suited to those in this stage of life has been termed "living apart together," or LAT.

LAT is a lifestyle in which the partners in a committed couple maintain separate residences. LATs typically spend several nights a week together, socialize together, vacation and spend holidays together, and yet each keeps his or her own home and separate finances. Because this makes it possible for seniors to combine independence with an intimate connection, LAT appears to be an attractive lifestyle for this group, as it permits them, among other things, to keep their own familiar space, preserve their inheritance for their children, and, in the case of women, protect themselves against gendered divisions of domestic labor characteristic of marriage.

Relying upon a number of sources, this paper examines LAT among Third Age adults. First, I explore the burgeoning literature on dating and partnership among older persons, as well as on sexuality and intimate relationships throughout this period of life. Second, I discuss research that has been done about LAT and persons in this age group, primarily by sociologists in Europe, Australia, and Canada. Third, I describe what my own empirical research has revealed about LAT among persons aged sixtyfive and over; my research was based primarily on a series of qualitative interviews I carried out in 2016 with individuals in that age group who were currently in LAT couples. In conclusion, I consider what the response of family law should be to this new lifestyle.

\section{New Attention to Sexuality and Intimate Relationships in Later Life}

The attention now being given to relationships in later life is not surprising, given that the group of persons over age sixty-five comprises

4. See, e.g., Life Expectancy at Birth, Total (Years), The World Bank, https://data. worldbank.org/indicator/SP.DYN.LE00.IN? contextual=max\&end=2015\&locations=US\&start $=1960 \&$ view $=$ chart (increasing longevity); Renee Stepler, Led by Baby Boomers, Divorce Rates Climb for America's 50+ Population, FactTank: News in Numbers, Pew Res. Ctr. (Mar. 9, 2017), http://www.pewresearch.org/fact-tank/2017/03/09/led-by-baby-boomers-divorce-ratesclimb-for-americas-50-population/.

5. The name LAT, although short for an English phrase, was originated by a Dutch journalist to describe the way in which he himself was living. Irene Levin \& Jan Trost, Living Apart Together, 2 COMMUNITY, WoRK \& FAM. 280, 281 (1999). 
almost $20 \%$ of the U.S. population over the age of eighteen. ${ }^{6}$ Slightly more than half of this group (53\%) are married, but the gender distribution both in numbers and in the percentage who are married is lopsided, leading some to describe a marriage market severely biased against women because about $73 \%$ of men sixty-five and older are married versus $43 \%$ of women. ${ }^{7}$ While some attribute the scarcity of men in this age group to the greater longevity of women, ${ }^{8}$ others contend that this is not the only factor, that women also appear to be choosing to remain unmarried after divorce or the death of a spouse, while men remarry. ${ }^{9}$ Only $5.2 \%$ of adults sixtyfive and older remarry, with the result that $41 \%$ of those in this age group were officially unpartnered in $2017 .{ }^{10}$ Being single, however, does not mean that persons in this group are uninterested in intimate relationships.

In this respect, it is important to consider who is currently entering the Third Age. Those who reached sixty-five in 2017 were born in 1952 and turned twenty in 1972. Sociological research on relationship patterns emphasizes the importance of looking at data from a lifecourse perspective, focusing on the common experiences of a particular age cohort, i.e., "people who are born into a cultural period marked by distinctive events and beliefs that have particular impact on individuals as they be come adolescent and move into adulthood."11 What was going on

6. Living Arrangements of Adults 18 Years and Over in the United States, U.S. CENSUS BUREAU, https://factfinder.census.gov/faces/tableservices/jsf/pages/productview.xhtml?pid=ACS_15 5YR_B09021\&prodType=table (last visited Mar. 21, 2018).

7. Id.; Sharon Sassler, Partnering Across the Life Course: Sex, Relationships, and Mate Selection, 72 J. Marriage \& FAM. 557, 566 (2010); Toni Calasanti \& K. Jill Kiecolt, Diversity Among Late-Life Couples, 31 Generations, no. 3, Fall 2007, at 10, 11. See also Matthew R. Wright \& Susan L. Brown, Psychological Well-Being Among Older Adults: The Role of Partnership Status, 79 J. MARRIAGE \& FAM. 833, 834 (2017) (reporting that $30 \%$ of men older than sixty-five were unmarried, as well as $60 \%$ of women).

8. See, e.g., Alinde J. Moore \& Dorothy C. Stratton, The "Current Woman" in an Older Widower's Life, in INTIMACY IN LATER Life 121, 122 (Kate Davidson \& Graham Fennell eds., 2004).

9. See, e.g., Jaroslava Hasmanová Marhánková, Women's Attitudes Toward Forming New Partnerships in Widowhood: The Search for "Your Own Someone" and for Freedom, $28 \mathrm{~J}$. WOMEN \& AGING 34, 35 (2016).

10. Huijing Wu, Nat'l Ctr. for Fam. \& Marriage Res., Age Variation in the REMARRIAGE RATE, 1990 \& 2015, https://www.bgsu.edu/content/dam/BGSU/college-of-artsand-sciences/NCFMR/documents/FP/wu-age-variation-remarriage-rate-1990-2015-fp-17-21. pdf; Richard Fry, The Share of Americans Living Without a Partner Has Increased, Especially Among Young Adults, Pew Res. Ctr.: FactTank: News in Numbers (Oct. 11, 2017), http:// www.pewresearch.org/fact-tank/2017/10/11/the-share-of-americans-living-without-a-partnerhas-increased-especially-among-young-adults/.

11. Huyck, supra note 1, at 13; Torbjörn Bildtgård \& Peter Öberg, Time as a Structuring Condition Behind New Intimate Relationships in Later Life, 35 AGEING \& Soc'Y 1505, 1509 (2014) (emphasizing importance of life course theory). 
when the Baby Boom generation reached young adulthood? This was the rebellious generation who challenged not only the politics of their elders in the civil rights, antiwar, and women's movements but also their values and lifestyle. This was the generation of the so-called sexual revolution, when sex outside of marriage became common and women began to insist on sexual satisfaction for themselves, relying upon the availability of the contraceptive pill and abortion. No-fault divorce became available, divorce rates rose, ${ }^{12}$ and divorce was no longer considered exceptional or stigmatized. As of $2015,14.3 \%$ of men and $18.1 \%$ of women in the United States had been divorced at least once, and rates of cohabitation more than doubled for men and more than tripled for women between 1990 and 2015. ${ }^{13}$ The Baby Boom generation wrote new rules about intimate relationships and experimented with a plurality of new forms, and those same men and women have continued to do so into their Third Age.

One sign of this phenomenon is the proliferation of books and articles about sexuality and older persons. My quick check of Amazon.com listings returned about twenty-five books with the words "sex after sixty" in their titles. Most of these were popularized and advice volumes, but scholars, especially gerontologists, have also turned their attention to this topic. While early social science and medical studies of sexuality largely ignored this age group, Bernard D. Starr and Marcella Bakur Weiner carried out a survey in 1981 in which they asked participants very detailed questions about their sex lives, eliciting responses from 800 people between the ages of sixty and ninety-one. ${ }^{14}$ They reported that the need for physical contact was powerful from infancy throughout life and that "older people indeed [are] interested in sex, they also think about it, desire it, and engage in it when they can, with the same average frequency that Kinsey reported for his 40-year-olds." ${ }^{15}$ A more recent study of a large national probability sample reported that $67 \%$ of men and $40 \%$ of women between ages sixty-

12. See D. Kelly Weisberg \& Susan Frelich Appleton, Modern Family LaW 479-80 (6th ed. 2016).

13. Susan L. Brown \& Matthew R. Wright, Marriage, Cohabitation, and Divorce in Later Life, 1 InNOVATION IN AGING 1, 2 (2017), https://academic.oup.com/innovateage/article/1/2/ igx015/4157719.

14. Bernard D. Starr \& Marcella Bakur Weiner, The Starr-Weiner Report on Sex \& Sexuality in the Mature Years (1981). See Toni M. Calasanti \& Kathleen F. Slevin, Gender, Social Inequalities, AND Aging 80 (2001) (regarding disregard of sex among the elderly by Kinsey and other sex researchers). Indeed, a major sex survey in the UK as late as 2000 included no one above the age of forty-four in the sample. Kate Davidson \& Graham Fennell, Introduction: New Intimate Relationships in Later Life, in INTIMACY IN LATER LIFE viii (Kate Davidson \& Graham Fennell eds., 2004).

15. StARR \& WeINER, supra note 14 , at 9, 35 . 
five and seventy-four still engaged in sex; $65 \%$ of those engaged in sex two to three times a month or more often and regarded sexuality as an important part of their lives. ${ }^{16}$ This research has led to concern among nursing homes as to how to accommodate these needs among their residents. ${ }^{17}$

Pharmaceutical aids such as Viagra caused feminist scholars to raise some concerns about this new focus. Due to normal physical changes associated with aging, sexual intercourse becomes more difficult for both men and women as they get older, potentially leading to the need for a reconsidered definition of sex, changing it from a penetration-based definition and refocusing upon touch, caressing, cuddling, and more diffuse, varied, and relational expressions of sexuality between partners. ${ }^{18}$ Yet the extensive promotion and use of Viagra and similar products plays into traditional male-oriented notions of sex as a goal-oriented performance, sacrificing an opportunity for men and their partners to develop more egalitarian and mutually satisfactory physical relationships in later life. ${ }^{19}$ Whether women can successfully confront this masculine construction of sexuality or not as the Baby Boom generation enters old age, there is evidence that both men and women desire a continuation of their sexual lives. Indeed, scholars have pointed out that this period, which is both post-reproductive and post-productive - in other words, the "empty nest" and retirement stage of life - is a time when, for the first time, life may not be reserved for projects imposed by the outside world, allowing for the development of new and more profound intimate relationships. ${ }^{20}$

16. Stacy Tessler Lindau et al., A Study of Sexuality and Health Among Older Adults in the United States, 357 N. Eng. J. Med. 762, 766, 772 (2007). Even among those in the group from seventy-five to eighty-four, $39 \%$ of men and $17 \%$ of women were sexually active. Id. at 766. A 1999 AARP poll confirmed the importance of sex to quality of life among older adults. CALASANTI \& SLEVIN, supra note 14, at 81.

17. See, e.g., Donna J. Rankin, Intimacy and the Elderly, 38 Nursing Homes Senior Citizen CARe 10 (1989); Winnie Hu, Too Old for Sex? Not at This Nursing Home, N.Y. Times (July 12, 2016), https://www.nytimes.com/section/nyregion?action $=$ click\&contentCollection=N.Y.\%20 $\% 2 \mathrm{~F} \% 20$ Region\&module $=$ Kicker\&region $=$ Header\&pgtype $=$ article.

18. See, e.g., CAlasanti \& Slevin, supra note 14, at 89-91. Post-menopausal women experience vaginal changes, including both less lubrication and a thinning of the vaginal wall that make intercourse painful for many, while older men have difficulty obtaining and maintaining an erection. $I d$. at 82-83.

19. See id. at 85-91. See also Ingrid Arnet Connidis, Intimate Relationships: Learning from Later Life Experience, in Age Matters: ReALIgning Feminist Thinking 123, 141-43 (Toni M. Calasanti \& Kathleen F. Slevin eds., 2006).

20. Bildtgård \& Öberg, supra note 11, at 1514-15, 1522. The authors speak of this possibility as the result of both having time and having a sense that the time remaining is limited. $I d$. at 1516-18; see also id. at 1521; Connidis, supra note 19, at 129 (pointing out that individuals today spend longer in a life stage not dominated by work, allowing them to redefine gender relations). 
Scholars of sociology, demography, and gerontology, in particular, have turned their attention to the types and quality of intimate relationships among adults of the Third Age. There is some disagreement about how exactly an intimate relationship should be defined and, specifically, whether a sexual relationship is a necessary part of it. One author, for example, defines an intimate relationship as involving "commitment, affection, cognitive intimacy, and mutuality," but she calls it a romantic relationship only if it includes erotic and sexual intimacy; others use the phrase "intimate relationship," as I do, to refer to a relationship that includes all these aspects. ${ }^{21}$ Nevertheless, there is general agreement that many older adults are currently involved in intimate, nonmarital relationships of a variety of sorts, with a primary motivation being their desire for companionship, as well as for physical affection. ${ }^{22}$ Although cohabitation among this age group has increased, it is still chosen only by a small minority compared to the number of couples in non-co-residential relationships. ${ }^{23}$ Research on this phenomenon has commonly been referred to as studies of "dating" among older adults; the earliest scholars in this field found that $90 \%$ of the daters they studied were sexually active with one another and monogamous for the most part. ${ }^{24}$

One study relying on data from the 2005-2006 National Social Life, Health, and Aging Project reported that, of the 3,005 individuals between the ages of fifty-seven and eighty-five who participated, $27 \%$ of unmarried men and $7 \%$ of unmarried women ages sixty-five to seventy-four, and $24 \%$ of men and $3 \%$ of women ages seventy-five to eighty-five, were dating. ${ }^{25}$

21. Huyck, supra note 1, at 9. Compare Connidis, supra note 19, at 126 (defining intimate relationship as including "commitment, deep feelings and expressions of caring and compassion, thinking about another and sharing values and goals, physical intimacy ranging from close proximity to sexuality, and interdependence").

22. See, e.g., Teresa M. Cooney \& Kathleen Dunne, Intimate Relationships in Later Life: Current Realities, Future Prospects, 22 J. FAM. Issues 838, 853 (2001); Wendy K. Watson \& Charlie Stelle, Dating for Older Women: Experiences and Meanings of Dating in Later Life, 23 J. WoMen \& AGING 1, 2-3 (2011).

23. Wright \& Brown, supra note 7 , at 3 (reporting that older adult cohabitation increased almost threefold between 2000 and 2013); Calasanti \& Kiecolt, supra note 7, at 15 (reporting that cohabitants constituted only $3.7 \%$ of unmarried men and $0.9 \%$ of unmarried women aged sixty-five or older). Both remarriage and cohabitation are uncommon among women who are widows. Sara M. Moorman et al., Women's Romantic Relationships After Widowhood, 27 J. FAM. ISSUES 1281, 1285 (2006).

24. Richard A. Bulcroft \& Kris A. Bulcroft, The Nature and Functions of Dating in Later Life, 13 Res. ON AgING 244, 246 (1991); see also Kris Bulcroft \& Margaret O'Connor, The Importance of Dating Relationships on Quality of Life for Older Persons, 35 FAM. ReL. 397, 399 (1986) (describing dating as a monogamous relationship).

25. Susan L. Brown \& Sayaka K. Shinohara, Dating Relationships in Older Adulthood: A National Portrait, 75 J. MARRIAGe \& FAM. 1194, 1196-97 (2013). 
The resulting statistics and studies about the motivations of these individuals and the quality of their relationships, especially studies comparing widows and widowers, reveal profoundly gendered results. Widowers, who have typically relied upon their wives for both social connections and as their only emotionally intimate confidante, feel lonely and isolated; they also may not be skilled at domestic tasks and feel depressed being alone. ${ }^{26}$ Widows, by contrast, have traditionally been the keepers of kin and social networks; they have relied on these networks during marriage, find them still there as support during widowhood, and fear losing them if they remarry. ${ }^{27}$ They also enjoy the independence that being single allows. ${ }^{28}$ The health and well-being statistics for older women and men living alone versus those who are married reflect these differing characteristics and capacities, showing that there is little mental or physical advantage to older women from remarriage, although there is substantial advantage to men. ${ }^{29}$ Moreover, $40 \%$ of older adults' income is from Social Security, so that women's need to rely upon husbands for economic support is reduced at this time of life; indeed, both alimony and Social Security drawn on a previous divorced husband's account may be lost if they remarry. ${ }^{30}$ Finally, study after study reports that older unmarried women are not eager to take on the tasks of caretaking for another person. ${ }^{31}$ In short, Third Age women, most of whom have been married before and are either widowed

26. Deborah Carr, The Desire to Date and Remarry Among Older Widows and Widowers, 66 J. MARRIAGE \& FAM. 1051, 1053-54 (2004).

27. Calasanti \& Kiecolt, supra note 7, at 14; Marhánková, supra note 9, at 36.

28. One study showed a stark gender difference in reasons given for not remarrying, with more than half the widows in the study, and none of the widowers, saying that they enjoyed their freedom. (Virtually all the widows and none of the widowers cited not wanting to look after another person.) Kate Davidson, Gender Differences in New Partnership Choices and Constraints for Older Widows and Widowers, in INTIMACY IN LATER LifE 65, 76 (Kate Davidson \& Graham Fennell eds., 2004).

29. Wright \& Brown, supra note 7 , at 3-4.

30. Carr, supra note 26, at 1053; see also Cooney \& Dunne, supra note 22, at 848 . Many states follow the Uniform Marriage and Divorce Act (UMDA) provision that automatically terminates alimony upon remarriage. NAT'L CONF. OF COMM'ERS ON UNIFORM STATE LaWS, Uniform MarRiage AND Divorce ACT § 316(b) ("Unless otherwise agreed in writing or expressly provided in the decree, the obligation to pay future maintenance is terminated upon the death of either party or the remarriage of the party receiving maintenance."). In some states, alimony is terminated upon cohabitation as well. Emily M. May, Should Moving in Mean Losing Out? Making a Case to Clarify the Legal Effect of Cohabitation on Alimony, 62 DuKE L.J. 403 passim (2012). See also Benefits Planner: Retirement, If You Are Divorced, Soc. SECURITY ADMIN., https://www.ssa.gov/planners/retire/divspouse.html (last visited Mar. 21, 2018) (concerning possible loss of social security benefits on a previous spouse's account in the case of remarriage).

31. See, e.g., Carr, supra note 26, at 1064; Connidis, supra note 19, at 138. 
or divorced, typically revel in their newfound and/or painfully constructed independence and are reluctant to give it up to remarry or cohabit. ${ }^{32}$

Some of these studies of dating among older adults were in fact studies of people living apart together. As I describe below, many of the same motivations seem to be present. However, authors writing since LAT has been noticed as a social phenomenon distinguish it from dating, presumably as a somewhat more committed form of relationship. ${ }^{33}$ And article after recent article notes, typically in its conclusion, that LAT may be the ideal relationship for persons in the Third Age. ${ }^{34}$ Yet LAT is virtually unstudied in the United States; for that research, we must turn to studies from Scandinavia, the Netherlands, France, Australia, and Canada, which I describe in Part II.

\section{What We Know from Previous Studies of LAT and Older Adults}

LAT as a phenomenon, whether a new family form or simply a new way of being single, has for some time attracted the attention of scholars in Europe, who have already subjected these couples to empirical analysis. ${ }^{35}$ Many of these studies have focused on older LATs, typically meaning those who are past the age of childrearing, and subgroups among them, such as those who are retired or approaching retirement. In this Part, I first describe the results of those studies, focusing on statistics about LATs in this age group, how they live, their reasons for living apart, the gendered nature of their responses, and the implications for caregiving of the aged. I then describe the small amount of research available on this subject in the United States, as well as some anecdotal information about older LATs available in the U.S. news media.

\section{A. What We Know from Research on Third Age LATs in Other Countries}

\section{Statistics}

One study in the Netherlands, based on a 1992 survey of persons between the ages of fifty-five and eighty-nine, found that, of those who

32. See, e.g., Marhánková, supra note 9 , at 39.

33. See Brown \& Shinohara, supra note 25, at 1201 (seeing LAT as a next step for older daters).

34. See, e.g., Marhánková, supra note 9 , at 43; Carr, supra note 26, at 1065; Sassler, supra note 7, at 566; Moorman et al., supra note 23, at 1301; Connidis, supra note 19, at 137-38.

35. See, e.g., Simon Duncan \& Miranda Phillips, People Who Live Apart Together (LATs): New Family Form or Just a Stage?, 21 InT'L REV. Soc. 513 (2011). 
had repartnered after divorce or the death of a previous partner, 55\% had remarried, $21 \%$ were cohabiting, and $24 \%$ were LAT, with those fiftyfive and over being three times more likely to be in LAT relationships than persons younger than they were. ${ }^{36}$ Of those who had started a new partner relationship at the age of fifty or older, 32\% chose LAT (versus $28 \%$ cohabiting and $40 \%$ remarried). ${ }^{37}$ Indeed, a large percent of LAT relationships were entered into at the age of seventy or older. ${ }^{38}$ This appeared to denote something of a secular change, because men and women who repartnered before 1984 chose primarily to remarry, and those who repartnered after 1985 chose LAT. ${ }^{39}$

The other country in which extensive studies of this group of LATs are available is Sweden. In Sweden, the percentage of older LATs is comparatively high, with $5.1 \%$ of those aged sixty to ninety making up that group in $2014 .{ }^{40}$ The author of one recent article speaks of LAT as being "institutionalised in Nordic countries" and reports that the majority of persons he studied who were in new partner relationships after the age of sixty were LAT. ${ }^{41}$ In the UK, this group is less studied, in part because early surveys thought it was too sensitive to ask respondents over the age of sixty about their intimate living arrangements, ${ }^{42}$ but one study reports that $5 \%$ of all LATs in the UK were aged sixty-five to ninety-seven. ${ }^{43}$ In Canada, scholars found that $2.3 \%$ of all persons sixty and older were LATs in 2011, an increase from $1.8 \%$ in $2001 .{ }^{44}$ A French demographer reported in 2009 that $4.4 \%$ of partnered men and $6.8 \%$ of partnered women in France aged sixty to sixty-nine were LATs; the comparable figures for the seventy to seventy-nine age group were $3 \%$ of men and $3.1 \%$ of women. ${ }^{45}$ In short, the percentage of Third Age adults who are LATs in Europe and

36. Jenny De Jong Gierveld, Remarriage, Unmarried Cohabitation, Living Apart Together: Partner Relationships Following Bereavement or Divorce, 66 J. MARriage \& FAM. 236, 238, 240 (2004).

37. Jenny De Jong Gierveld, The Dilemma of Repartnering: Considerations of Older Men and Women Entering New Intimate Relationships in Later Life, 27 AGEING INT'L 61, 65 (2002).

38. $I d$.

39. Id. at 67 .

40. Jenny De Jong Gierveld, Intra-couple Caregiving of Older Adults Living Apart Together: Commitment and Independence, 34 CANADIAN J. ON AgING 356, 357 (2015).

41. Bildtgård \& Öberg, supra note 11, at 1507, 1511.

42. John Haskey \& Jane Lewis, Living-Apart-Together in Britain: Context and Meaning, 2 INT'L J.L. IN CONTEXT 37, 39 (2006).

43. Simon Duncan \& Miranda Phillips, People Who Live Apart Together (LATs)-How Different Are They?, 58 Soc. Rev. 112, 122 (2010).

44. Martin Turcotte, Statistics Canada, Living Apart Together 4 (2013).

45. Arnaud Régnier-Loilier et al., Neither Single, nor in a Couple: A Study of Living Apart Together in France, 21 DemOGRAPHIC RES. 75, 87 (2009). 
Canada ranges between 2\% and 5\% and appears to be increasing, although at different rates in different national environments.

A good description of the living arrangements of these couples appears in a study of Swedish LATs between the ages of sixty and ninety. ${ }^{46}$ These couples, about half of whom were divorced and $40 \%$ of whom were widowed, maintained separate residences and, by and large, separate finances; $79 \%$ had no joint savings of any kind; and more than $85 \%$ shared no possessions at all. ${ }^{47}$ The partners typically lived close to one another, with more than half meeting a couple of times a week and $36 \%$ almost daily. ${ }^{48}$

\section{Reasons for Living Apart}

The reasons that older couples live apart are particular to this age group. While younger LATs may be constrained by the presence of jobs or children in different locations, ${ }^{49}$ Third Age couples are largely free from these constraints. The Dutch LATs described in the studies above, for example, spoke of their desire to continue living in a familiar setting, to be able to make independent decisions about their daily activities, and to avoid having to make the adjustments that would be required if they shared a residence. Repartnering as a LAT was simply less stressful. ${ }^{50}$ Swedish women in LAT relationships also mentioned the importance of autonomy, as well as the ability to choose their own daily activities and to avoid the difficulty of adapting to a new partner's ways. ${ }^{51}$ Some older LATs also said that living apart was good for their relationships as it allowed them to escape the daily struggles of living together. ${ }^{52}$

For many Third Age LATs, their own homes represent both a connection to the past and a long-term investment in a particular neighborhood. ${ }^{53}$ These are the places where children and grandchildren come to visit, and

46. Sofie Ghazanfareeon Karlsson \& Klas Borell, Intimacy and Autonomy, Gender and Ageing: Living Apart Together, 27 AgEING INT'L 11, 14 (2002) [hereinafter Intimacy and Autonomy].

47. Id. at $14,19$.

48. Id. at 15 .

49. See Cynthia Grant Bowman, How Should the Law Treat Couples Who Live Apart Together?, 29 CHILD \& FAM. L.Q. 335 (2017).

50. De Jong Gierveld, supra note 37, at 74-76.

51. Ghazanfareeon Karlsson \& Borell, supra note 46, at 17, 23.

52. Vincent Caradec, Les Formes de la Vie Conjugale des "Jeunes" Couples "Âgés," 51 Population 897, 907 (1996) (subsequently published as Forms of Conjugal Life Among the "Young Elderly," 9 Population: An English Selection 47 (1997)).

53. "[L]a maison est le lieu des souvenirs" [home is the place of memories], according to one French scholar. Id. at 905. 
they are thus important to relationships with them, as well as assets the parents want to preserve for the younger generation. ${ }^{54}$ An older person's home is also an important source of financial security and is likely his or her largest asset, and many thus want to keep their own homes for reasons that are both emotional and economic. ${ }^{55}$ If they were to remarry, moreover, they would risk losing pension rights and other benefits in some countries. ${ }^{56}$

In addition, many older people link keeping their own homes to autonomy and independence. ${ }^{57}$ Women express this reason in particular, arguing that home is a place of one's own where a woman can be her authentic self rather than losing her own identity by becoming half of a couple. ${ }^{58}$ Women are also eager to "avoid an asymmetrical distribution of household labor and unequal demands of caring for a partner[,]" which they may have experienced in prior unions. ${ }^{59}$ They emphasize that age has finally given them the opportunity to live without responsibilities for others and to devote time to friends and outside interests of their own. ${ }^{60}$ These particularly female reasons for living apart have led some commentators to conclude that the LAT phenomenon represents the "gender revolution continuing into old age[,]" as the women in that age cohort were those "who have been pioneers of the restructuring of family life in the past thirty to forty years." 61 A study of Canadian LATs points out, similarly, that the majority of older LATs grew up in the 1960s and challenged social norms but were now more set in their ways and also financially independent, so that they did not need to cohabit. ${ }^{62}$ By contrast, in a UK study of widows over the age of sixty-five, the LATs who had been born before 1930 - that is, who were in age cohorts prior to the Baby Boom - described their lives as "selfish," by which they meant being able

54. Anna Reimondos et al., Living-Apart-Together (LAT) Relationships in Australia, 87 FAM. MATTERS 43, 53 (2011); De Jong Gierveld, supra note 37, at 73-74; Caradec, supra note 52 , at 906.

55. Caradec, supra note 52, at 906.

56. Id. at 911. But see De Jong Gierveld, supra note 37 , at 72 (only private pensions may be lost in the Netherlands upon remarriage, not the state pension to which everyone is entitled).

57. Caradec, supra note 52, at 907 (France); De Jong Gierveld, supra note 37, at 71-72 (Netherlands); Laura M. Funk \& Karen M. Kobayashi, From Motivations to Accounts: An Interpretive Analysis of "Living Apart Together" Relationships in Mid- to Later-Life Couples, 37 J. FAM. ISSUES 1101, 1107-1110 (2016).

58. Sofie Ghazanfareeon Karlsson \& Klas Borell, A Home of Their Own: Women's Boundary Work in LAT-Relationships, 19 J. AgING STUdies 73, 74-75 (2005).

59. Ghazanfareeon Karlsson \& Borell, supra note 46, at 24.

60. Funk \& Kobayashi, supra note 57, at 1116.

61. Ghazanfareeon Karlsson \& Borell, supra note 46, at 23-24.

62. Funk \& Kobayashi, supra note 57, at 1113-14. 
to do what they wanted, when they wanted, without having to care for or consider the needs of a partner. ${ }^{63}$ The Baby Boomers perhaps saw what the older women described as selfish as a continuation of rights they had sought throughout their lifetimes.

\section{Implications for the CARE of the Elderly}

LAT clearly has repercussions for caretaking of the elderly. This is a theme explored by many of the studies described above. This policy issue has become more salient in light not only of the aging of the population but also of its changing age distribution. Its representation on a graph has gone, as one author put it, from a pyramid-like structure to a beanpole; in other words, the decreasing birth rate has resulted in fewer children and grandchildren upon whom older adults can depend for care later in life. ${ }^{64}$ In the face of this problem, the governments of some countries, such the Netherlands, have even passed legislation imposing responsibilities on partners and children to care for their aging parents. ${ }^{65}$

Some studies have reported that, although LATs support one another in their daily activities, they lag behind co-residential partners in caregiving in illness. ${ }^{66}$ One study of 116 LATs between the ages of sixty and ninety found that many LATs expressed themselves willing to offer care for their partners in old age, but they did so in Sweden, where very-high-quality, state-provided care and services are available for the elderly ${ }^{67}$ Both men and women in the Swedish study reported receiving more care from their LAT partners than from relatives and friends, with women expecting less care and men reporting receiving more care than women. ${ }^{68} \mathrm{~A}$ study of older LATs in Canada showed good intentions but mixed feelings about expecting care from a partner; the ambivalence was particularly strong about accepting, rather than offering, care. ${ }^{69}$ When asked about whether they had actually experienced receiving or giving care from or to a partner, however, more than half the LATs interviewed in one Dutch study reported that they had in fact done so, causing the author to conclude that

63. Kate Davidson, Late Life Widowhood, Selfishness and New Partnership Choices: A Gendered Perspective, 21 AgEING \& Soc'Y 297, 305-08 (2001).

64. Sofie Ghazanfareeon Karlsson \& Majen Espvall, Intimacy and Obligations in LAT Relationships in Late Life, in Couple Relationships in the Middle and Later years: Their Nature, CompleXity, AND Role In Health ANd Illness 85 (Jamila Bookwala ed., 2016).

65. De Jong Gierveld, supra note 40, at 357.

66. $I d$.

67. Ghazanfareeon Karlsson \& Borell, supra note 46, at 14, 20.

68. Sofie Ghazanfareeon Karlsson et al., Caring While Living Apart, 49 J. Gerontological SOC. Work 3, 17-24 (2007).

69. De Jong Gierveld, supra note 40, at 359-62. 
"[o]lder long-term LAT partners are indeed involved in reciprocal care exchanges." ${ }^{70}$ While need for this care may vary with the national setting and in particular the social services provided by the state, LAT partners can be an important part of an overall response to the increased needs for care that arise in old age.

\section{B. What Little We Know from Past Studies of Third Age LATs in the United States}

LATs have been virtually unstudied in the United States, but one of the few articles published is about older LATs. ${ }^{71}$ That study was of twenty-five LATs between the ages of sixty and eighty-eight who had been in their current relationships from seven months to twenty-seven years, with $92 \%$ of them having been previously married. ${ }^{72}$ Eleven of the twenty-five said they saw LAT as superior to both marriage and cohabitation. ${ }^{73}$ When asked about their reasons for choosing this type of relationship, the respondents emphasized their desire for an intimate companion while maintaining their personal autonomy. ${ }^{74}$ They mentioned their wish to avoid their partner's negative traits and bad habits, such as differences in housekeeping, home decorating, or hobbies, yet spoke of wanting an intimate and committed relationship with the trust and companionship of marriage but without its negative components. ${ }^{75}$ Specifically, they wanted to avoid the physical, financial, and emotional burdens of being the caregiver of an aged partner. ${ }^{76}$ Their desire was to avoid any structural or legal commitment, such as the obligations that would accompany marriage. ${ }^{77}$ Living separately addressed this need for protection, which the authors opined might be uniquely American, driven by the lack of social assistance for the aging such as would exist in Europe. ${ }^{78}$ They speculated that LAT may be a new way of "conceptualizing and operationalizing commitment" that was appropriate to this later stage in life. ${ }^{79}$

70. Id. at 361,363 .

71. Jacquelyn J. Benson \& Marilyn Coleman, Older Adults Developing a Preference for Living Apart Together, 78 J. MARRIAGE \& FAM. 797 (2016). The other scholarly article on this subject does not focus on Third Age LAT couples. Charles Q. Strohm et al., "Living Apart Together" Relationships in the United States, 21 Demographic Res. 177 (2009).

72. Benson \& Coleman, supra note 71, at 800.

73. Id. at 806 .

74. Id. at 802 .

75. Id. at 804,809 .

76. Id. at $803-04$.

77. $I d$. at 803,808 .

78. Id. at 808-09.

79. Id. at 810 . 
The only other source of information about older LATs in the United States is the news media. One article that appeared in the Real Estate section of the New York Times in 2013 presented LAT as especially suited to older New Yorkers who were set in their ways and their neighborhoods ${ }^{80}$ It described, for example, a couple in their seventies who each lived in rentstabilized apartments neither wanted to give up (although they said they might be willing to move in with one another if either became seriously ill). ${ }^{81}$ Another article that appeared about the same time in Newsday spoke of LAT as a growing trend for couples who were older, owned real estate, and had grown children. The article highlighted an interview with an eighty-nine-year-old man who had joined a bereavement group fourteen years earlier and reported that each man in the group now had a LAT partner, with the exception of one who had remarried. ${ }^{82}$

Other Third Age LATs described how they enjoyed living close to one another but in separate residences, traveling together, spending holidays together, and being involved in one another's family gatherings, yet said that marriage would complicate their "retirement funds, real estate and families from past marriages, in addition to intricate inheritance issues"; they wanted to keep both their financial and personal independence. ${ }^{83}$ One sixty-seven-year-old widower opined that marriage was for establishing a family, and both he and his partner had already raised their children, some of whom had returned to live at home as adults. So, spending one night during the week and weekends together allowed them each to accommodate their different pursuits; "it also," he said, "fuels desire." 84 The Newsday article included photos of one LAT couple who were eightynine and seventy-seven years old and had been together for eleven years and another who were seventy-seven and seventy-four and had been together for sixteen years. A couples therapist who was interviewed said

80. Constance Rosenblum, Living Apart Together, N.Y. TIMES (Sept. 13, 2013), http://www. nytimes.com/2013/09/15/realestate/living-apart-together.html.

81. Id. This couple had in fact been LATs for forty-two years and married for six years.

82. Paula Ganzi Licata, Unwedded Bliss: For Some Loving Couples, Happiness Is Keeping Their Homes, Finances and Routines Separate, NewsDAY, June 22, 2013, at B4. A similar article appeared in a Canadian magazine at about the same time. Manisha Krishnan, Living Apart, Together: 1.9 Million Canadians, Many 60-Plus, Are Saying No to Cohabitation and Marriage, MACLEANS MAG. (Sept. 17, 2013), http://www.macleans.ca/society/life/living-apart-together/ (describing lifestyle of older Canadian LATs, including one couple who had been together for sixteen years and who were ninety-one and ninety-four years old). In Canada, maintaining separate residences is also important because cohabitation gives rise to rights to support for the so-called common-law partner. Id. See also Cynthia Grant Bowman, UnMarried Couples, LAW, AND Public Policy 188-91 (2010).

83. Licata, supra note 82 , at B4.

84. Id. 
that LAT appealed to older couples with established routines and could work well if the partners communicated well and made adequate time for emotional and physical closeness; acceptance by family and friends was also helpful. ${ }^{85}$ The one problem noted was the possibility of a partner's hospitalization where a strict family-only policy might prevent the other partner from visiting.

\section{Results of New Empirical Research on Third Age LATs}

In 2016, I submitted eighteen questions about LAT to New York State and national surveys carried out annually by the Cornell Survey Research Institute, the former with 800 respondents and the latter with 1,000 . I have reported on the results of that research, as well as on its gendered dimensions, in two previous articles. ${ }^{86}$ However, the number of respondents to the two surveys who were sixty-five or older was too small to provide meaningful information about this group.

During 2016, I also conducted lengthy interviews with LATs who lived in New York City and Ithaca, New York. ${ }^{87}$ Many of them fell into the age group I am considering here. Only one couple, however, had entered the LAT relationship during the Third Age; for all the rest, LAT was a longterm lifestyle. These interviews, which I carried out separately with each member of most of the couples, yielded many insights into how LAT works for them at this age. To illustrate, I have selected four couples to discuss in this article; three were different-sex partners and one was a lesbian couple.

\section{A. A Cross-Section of Representative LAT Couples}

\section{Alice AND BeN ${ }^{88}$}

Alice and Ben had known one another for a long time when they got together as a LAT couple in their fifties. Both were, and still are, in the artistic community in New York City. Each had been married, and Ben had just moved out of the home he shared with his wife when he became seriously involved with Alice. Alice had just bought a co-op apartment about five miles away from the studio where Ben lived. Ben never wanted

85. Id.

86. Bowman, supra note 49; Cynthia Grant Bowman, Living Apart Together, Women, and Family Law, 24 Cardozo J. Equal Rts. \& Soc. Justice 47 (2017).

87. The interviewees were selected both from people I knew and from others recommended by colleagues and friends. I have, by now, done twenty interviews in total, both in the United States and the United Kingdom.

88. All of the names used to refer to interview subjects are fictional. 
to get married again; Alice did at first but said she became less insecure as time went on, and she realized that their relationship was working well as it was.

The two spend every weekend together, always at Ben's apartment, and often go out to dinner or the theater together once during the week. They share their lives by phone when not together, once in the morning, usually sometime in the afternoon, and at night before going to bed. They take extensive foreign vacations and celebrate birthdays and holidays together. They, and all their friends, consider them to be a couple; no one would invite one without the other. Although they talked about possibly getting a place together at the beginning of their relationship, they never went so far as to look at real estate. Both owned their apartments, and finding someplace new would be costly; besides, each liked his or her own home and did not want to give it up for a variety of reasons.

For Alice, LAT allows her to have her own things and to do things her own way when she is at home. The partners' tastes in furniture and home décor are quite different, and her own apartment is full of things that are meaningful to her. In addition, she likes having a space of her own and time to spend alone with her friends; she would not want to see Ben all the time, as would happen if they lived together. For Ben, having his own place is critical to his privacy; he needs time and space alone in order to write and likes to follow what he describes as his own patterns and systems of living. Alice's place is too cluttered for him and seems claustrophobic. And in New York, he says, "you don't give up an apartment."

Alice and Ben are compatible in other ways: They both like music and theater; neither is a sports fan; they enjoy travel; and they keep similar sleeping hours. Although each has a set of friends, they appear to be one another's first confidant, turning to one another to talk about problems and to seek comfort. They accompany one another to doctors' visits and are there for one another in case of illness, accident, or surgery. When asked whether they considered each other "family," Alice said yes, and Ben listed the following family functions they performed for each other: going to the doctor, discussing medical problems, making love, making meals together, traveling, seeking out entertainment, and providing emotional support. Each is the main beneficiary of the other's will and also serves as the other's health care proxy.

When on vacation or out together, Alice and Ben share the expenses roughly fifty-fifty, although Ben tends to pick up the tab for dinners out, not only because he has more money but also because, born in the 1930s, he regards this as part of being a gentleman. Neither pays any of the other 
person's living expenses, but either would help out the other in financial difficulty and have in fact done so when facing "cash flow" problems.

Ben cannot remember a time he didn't like being a LAT, and he and Alice have been together twenty-five years. Although sometimes she wishes he were there, Alice thinks the relationship has worked well for them overall, even though it is "not a lifestyle I would have ever thought of." She thinks they are closer than other couples she knows and attributes that to not being together all the time.

\section{CAROL AND DAN}

Carol and Dan, together twenty-nine years, are more typical of the Baby Boom generation, both having been involved in radical politics when they were young. Carol was previously married but felt stifled by that institution, while Dan has never been married. They are now both in their early seventies.

Like Alice and Ben, Carol and Dan live in separate apartments in different parts of New York City, but it takes about an hour to traverse the distance between them by subway. Because Dan is the cook and entertainer of the two and regards Carol's home as somewhat messy, they always spend their time together at his apartment. Dan is retired but works part time, while Carol still works all week long, so they only get together on Saturdays and Sundays, with occasional dates and phone calls in between, largely because of her schedule and the distance between their homes.

The two come from different ethnic groups and seem to have different personalities. Dan is outgoing, while Carol is not as social and is, indeed, somewhat reclusive. He likes loud music; she does not. He cooks; she cleans up. They go on at least one vacation together every year and usually two, one in the United States and one in Europe, but they also travel sometimes separately. Carol gets up very early and has different hobbies than Dan; he is sometimes jealous of the time she spends on them. But they both enjoy going to theater, dance, movies, and new restaurants together, and they also talk animatedly about politics. They celebrate Thanksgiving weekend, New Year's Eve, and the Fourth of July as a couple and make a special occasion - a surprise each year - out of one another's birthdays. Because neither is religious, they spend a "Jewish Christmas" together, which Dan describes as Chinese food and a movie. They have many friends together and invitations are always issued to them both. When the attack on the World Trade Towers happened on 9/11, they immediately sought one another out for comfort.

Yet, as is typical of LATs, Carol and Dan are financially independent of each other with respect to their living expenses. They split joint expenses 
fifty-fifty, but he treats on Saturday night, which is regarded as "date night." They know little about one another's finances. Neither has a great deal of money, but Dan seems to have a bit more, and he helped Carol with a bridge loan for a deposit on her apartment. They own nothing together. Dan has left his apartment and most of what he owns to Carol in his will, while she has not gotten around to making one yet.

Each partner in this couple has done major caretaking for the other in cases of illness. Carol moved in and took care of Dan after he underwent both rotator cuff surgery and a hip replacement operation, and she also moved in - once for as long as two weeks-so he could take care of her during convalescence from two hip replacements. They are clearly committed to taking care of each other.

At the beginning of their relationship, Dan wanted to live together, but Carol was adamantly opposed based on her feelings of having lost her identity and independence in her previous marriage. Even though they have discussed whether getting married would be financially advantageous for them, the discussion was premised on the assumption they would continue to live separately. Only once, when Dan was contemplating moving to another city, did they consider living together, with Carol asking if they could get a big enough place to live that would enable them to get away from each other if they did. Sometimes Dan feels lonely and would like to see more of Carol, but they have settled into the arrangement they have, which seems to work for them. Given their ease of traveling together, he thinks they could live together if they wanted.

\section{FRAN AND JEFF}

The third couple has been together almost twenty years, spanning differences of race, class, and religious background. Fran and Jeff are in their mid-seventies and both come out of the anti-racist, anti-imperialist, and feminist struggles of the 1960s and '70s, from which they have never distanced themselves. Both are retired now, but Fran in particular is still politically involved. Like many Leftists, they often find political questions on which they differ and dispute them.

Each has been married before, Fran twice, and she would never do so again. Fran says that she felt hemmed in psychologically when she was married. Jeff felt betrayed by his wife's infidelity and is very attached to the large rent-stabilized apartment in which they raised their children. If he were to give up this apartment, he would be unable to afford living anywhere in New York City. By comparison, Fran is economically privileged, having inherited a large co-op apartment from her second husband. The two apartments are six blocks apart. Each has grandchildren 
who live in the western part of the United States, and they are both very attached to their children and grandchildren, visiting them often.

When they first got together, Fran wanted Jeff to move in with her, but he was determined never to live together. While it took some years to resolve this difference, both are very satisfied with the arrangement now. Although Fran says she is lonely sometimes and wants the comfort of his body there with her, she is happy with being LATs overall. Fran likes to have solitude in which to practice her music and be with her pets, and she also gets up earlier and is much more programmed with activities than Jeff. Having their own space is extremely important to both of them, and their styles are also quite different - his cluttered and hers tidy. They virtually always spend their time together in her apartment, and she cooks for them when they eat in. Even though they are both retired now, they still keep up the pattern they established when working: spending weekends together; sometimes getting together during the week; going to concerts, movies, and the like; and talking by phone virtually every night. They regularly spend three to four weeks of a summer vacation together, have taken international trips together, and visit one another's children and grandchildren out West together. Fran's young grandchildren are very attached to Jeff and think of him as another grandfather. All the members of their immediate families think of them as a couple.

Although Fran and Jeff split the expenses of their joint entertainment and travels, this is done in proportion to their means, with Fran paying for any expensive travel Jeff would otherwise not be able to afford. He chips in for dinners and movies, while she pays for theater or music subscriptions and takes either Jeff or another friend along. They have no joint possessions, and although Fran has made some provision for Jeff in her will (Jeff has no will), her primary beneficiary and her health care proxy is her child. Fran and Jeff rely on each other to talk about problems. Although both say they would be there for the other in case of the health problems that accompany old age, they have not had many occasions to test this so far. Fran has long-term care insurance and says that, if worst came to worst, her children would probably insist on bringing her out to live near them and care for her.

Unlike Couples One and Two, Fran and Jeff are very close to their biological kin, but each says they think of themselves as immediate family to each other as well. They speak of their strong emotional bond and support and their fondness for one another's children. They share birthdays and holidays and grandchild occasions and photos. They are there for one another if sick or distressed and would provide material support of various sorts if necessary. It is clear that the LAT relationship works for both of 
them. Jeff says their relationship has lasted because of living apart and that they never would have made it if they spent $24 / 7$ together. This, he says, is partly because they met when they were older and set in their ways.

When I asked Fran whether she thought the law should treat them as a couple, she said no. Although she was willing to give support, she did not want an obligation to do so. Each of them has medical insurance from their prior employers, and there were no other measures they were not better off figuring out on their own, in her opinion. After consideration, however, she said that hospital visitation privileges would be one thing she would like to have.

\section{HANNAH AND ISABEL}

The final couple I have chosen to illustrate the LAT lifestyle is somewhat different from the three couples discussed above, both because they are a same-sex couple and because they previously lived together but now choose to live apart. They also do not live in New York City, but instead in Ithaca, New York, which includes a small academic town and the rural area surrounding it. They are now in their late sixties and have been together for almost forty years (with one four-year hiatus early on). They also come out of a 1960s Left political background. One is retired, and the other is not. They are very committed to one another and appear to have been so ever since their early thirties. They have been through a great deal together over the course of their lifetimes - deaths, cancer, eldercare for each of their parents, and caring for younger relatives. All the members of both of their families regard them as a couple and were surprised, if not fearful, when they decided to move apart.

Their moving apart happened gradually and is related to differences in habits and lifestyles. Hannah loves living in the country, is very domestic, is somewhat reclusive socially, and is fond of adopting pets that no one else wants. Isabel is very much a city person, even though she moved upstate from New York City, and she enjoys socializing, going out in the evenings, consuming cultural events, shopping, and the like. They also keep quite different hours, with Hannah going to bed very early and rising before dawn, and Isabel liking to stay up late at night and wake up later in the morning. Isabel is also less domestic, does not particularly like animals, and lives with more clutter around her. When they lived together, these differences and their personalities resulted in a somewhat volatile relationship.

At first, Isabel began to rent a pied-à-terre in town, about ten miles away from their joint residence, during the winter months because she hated driving in the winter, especially after dark. Eventually, the place 
where she was living came up for sale, and the two decided that she should acquire it. Hannah in fact helped purchase the downtown house and retains a one-fourth ownership interest in it, and they run an Airbnb out of it, with Hannah doing the administrative tasks and sharing in the profits. So, six years ago, Isabel moved all her things out of Hannah's house in the country and into town. They now spend weekends together, always in the country (because of all the pets to be fed and walked there), and they speak by phone multiple times a day, at the beginning and end of each day and several times in between. They also go on two lengthy (two-week-long) vacations together each a year.

The move turned out to be great for their relationship. The tension over living with animals, clutter, and sleep schedules disappeared, and each could pursue her own lifestyle without feeling guilty or as though she was having to tiptoe around the other. As Hannah said, "Half the issues went away, and others, we could walk away from. We didn't have to fight every fight; we could let it go. And we missed each other and were happy to be together when we were." Isabel agrees, saying they fought less, avoided power struggles, and "felt newer and fresher being together." It became the best of both worlds, resolving the tensions of being in the same house with each being able to have her own lifestyle and come together when they wanted to (although having a schedule helps avoid making this a constant decision-making process or negotiation).

Hannah and Isabel remain an extremely committed couple. Each brought elderly parents to Ithaca for care at the end of their lives, and each partner helped and supported the other through this difficult time. Hannah has taken a large role in bringing up a nephew with special needs, and he lived with her for some time. Isabel is fond of him and helps as she is able, sometimes with practical aid, such as giving him rides home, but more frequently by offering emotional support and advice to Hannah. The two women seem complementary in many respects, with Hannah possessing good practical skills and Isabel more adept at handling emotional and psychological issues. They share these skills with one another, Hannah by helping Isabel buy a car, for example, and Isabel by advising about care for Hannah's nephew or just listening empathetically. Each is committed to looking after the other in case of illness and has done so in the past, but each also realizes that Hannah is the better caretaker, but difficult to take care of. As she puts it herself, "I know that Isabel can't be my long-term care insurance."

Apart from the Airbnb and joint ownership of the house in which it takes place, Hannah and Isabel maintain separate finances, although they realize that may need to change when Isabel retires. They split joint expenses fairly 
evenly, although when Hannah made substantially more than Isabel in the past, they divided expenses according to ability to pay. Their manner of sharing expenses when on vacation is unusual: airfares and hotels are split fifty-fifty, but they alternate days to pay other expenses, so that only one has to worry about paying bills each day and can also choose to do things, such as go to a more expensive restaurant, that they might not do if both had to pay for it. As Isabel describes the arrangement, "We keep our money separate though we are very generous with one another; it balances out. We don't keep tabs but try to alternate. We have a kind of generosity of spirit around money." Sometimes they borrow from one another to address cash flow problems. With the exception of some bequests to relatives, their wills leave everything to one another, and they are listed as the beneficiaries of one another's bank and brokerage accounts.

Interestingly, this couplehas discussed marriage. Hannah is philosophically opposed to marriage, but they investigated whether it had advantages for them. They concluded that it did not. For example, neither had employerprovided health care that could cover her partner. Yet Isabel is a romantic and, although she realizes it does not suit Hannah's style, sometimes longs for a big community celebration now that marriage has become available to same-sex couples. Nevertheless, Isabel says, "We already feel married, whether legally or not. We are as committed as any married people are." Hannah regards LAT as a family form that is "a luxury."

\section{B. Some Common Themes and Conclusions Based on the Interviews}

The couples described above are all different, and yet they all illustrate many of the points made in the social science literature discussed in Part II. The interviews reveal a number of common themes, although with different permutations. All four couples are very close and committed; their commitment is indicated by the length of their relationships, among other things. They interact virtually daily, take long vacations with one another, share holidays and family visits, and spend several nights a week together. They typically spend their time together at the home of one partner-in two cases, at the apartment of the male - rather than alternating with one another. Each appears to have gradually shifted into the LAT arrangement, with one partner in three of the couples initially wanting to live together, but eventually deciding that LAT worked well, and with one couple experimenting with LAT 
after living together and finding that living apart suited them even better. ${ }^{89}$ Each pair is accepted by friends and family as a couple.

The reasons the interviewed LATs gave for living apart reflect many of those same reasons described in the literature. They want time together but also time to be with their friends and time to spend alone and engaged in their own pursuits, whether it be writing, piano, pets, or hobbies. Autonomy is important to these individuals, and the impact of previous marriages is clear in their opposition to marriage and their desire for independence. Different personal styles, especially in terms of clutter or mess versus tidiness and a preference for minimalist decor, figured into every couple's desire for individual personal space. Different biorhythms and personalities also played a role. The nature of the New York City real estate market was also mentioned as a factor by all the LATs who lived there. Interestingly, the need to hold on to apartments they could afford seemed more important to them than any long-term attachment to a particular home (with the possible exception of Jeff), such as was mentioned by LATs studied in Europe.

The LATs I interviewed differed from those in the literature in some other ways as well. Obligations to, and the preferences of, adult children did not seem to figure into their decisions to live apart together; nor did a desire to avoid a gendered division of labor. None mentioned the latter as part of their reasoning. In one couple, the man always did the cooking; in another, it was the woman; in a third, they shared the tasks of meal preparation. But in each case, the division of labor seemed to reflect genuine individual preferences - for example, one member of the couple really liked to cook - and living apart protected them from other sources of conflict over household work.

Moreover, although each LAT interviewed was financially independent, I noted a good deal of economic interdependence among them. Loans were common; all were interest-free and sometimes forgotten. Sharing expenses according to ability to pay was also common, and it was clear that each LAT was willing to assist the other financially if possible and necessary, although they did not want any formal obligation of support. One couple jointly owned real property and operated it as an Airbnb together. Many had made generous provision in their wills for their LAT partner.

Finally, all of the LATs I interviewed gave each other substantial amounts of emotional support as well as caregiving. Major medical caretaking had been done by members of three of the four couples, and all

89. The development of a preference for LAT over time appears to be common. See Benson \& Coleman, supra note 71 , at 807. 
professed themselves willing to give this type of care should it be needed. Some had also helped their partners with care of elderly parents or other family members. In short, the LAT couples I interviewed were fulfilling many of the functions of "family" for one another. The LAT relationship worked well for each couple, allowing each of them to live in their own spaces, in their own ways, while still having a deeply committed intimate relationship. All expressed satisfaction with the living arrangements they had worked out.

\section{Conclusion: LATs and Family Law}

If LATs are performing the functions of a family for one another, should they receive the protections of family law? My answer is neither an unequivocal "yes" nor an unequivocal "no." The LATs I interviewed were financially independent of one another with respect to the expenses of everyday life, and they all had a home of their own. The economic effect of separation or a partner's death would not be disastrous, although the financially weaker partner might no longer be able to enjoy travel and entertainment as they previously had. Moreover, the LATs appeared to value their independence very highly; although willing to offer support to one another, they rejected the idea of being legally obligated to provide either economic support or care. Because many of the protections of family law are premised on economic interdependence and consequent vulnerability upon death or divorce, these couples should not be covered by family law on a wholesale basis.

However, LATs also provide important caregiving functions for one another. Their efforts in this respect privatize the costs of these tasks, which may not be an ideal solution politically, but it can be necessary in a country that does not provide extensive public support for aging individuals who need care. The law should therefore support and facilitate LATs' mutual caretaking by, for example, extending hospital visitation rights to LAT partners, including them within the class of persons eligible for family and medical leave to care for a partner, making it possible for them to cover one another under their health insurance policies, and enabling them to receive pensions and bequests without taxation, as a spouse would be able to do. These changes would require amending both federal and state laws. Moreover, the law should not interfere with or punish LATs, for example, by using their living arrangements as a 
cause to terminate alimony from a partner's previous spouse, which has happened in some cases..$^{90}$

If welfare benefits, health care, and pensions were all based on status as an individual, rather than as a family, many of the problems described above would disappear. Because that does not seem likely in the United States, at least in the short run, the piecemeal legal reforms recommended will ease the lives of many older persons who have found that living with a partner but not sharing a home is the ideal arrangement for them.

90. See, e.g., Rehm v. Rehm, 409 S.E. 2 d 723 (N.C. App. 1991); Paul v. Paul, 60 A.3d 1080 (Del. 2012); In re Marriage of Herring, 634 N.E.2d 1168 (Ill. App. 1994); In re Marriage of Susan, 856 N.E.2d 1167 (Ill. App. 2006). 